\title{
Campesterol from Methanol Fraction of Brotowali (Tinospora crispa) Stem Bark
}

\author{
Weny J.A Musa \\ Department of Chemistry \\ Gorontalo State University \\ Gorontalo, Indonesia \\ weny@,ung.ac.id
}

\author{
Suleman Duengo \\ Department of Chemistry \\ Gorontalo State University \\ Gorontalo, Indonesia \\ sulemanduengo@,ung.ac.id
}

\author{
Ahmad Kadir Kilo \\ Department of Chemistry \\ Gorontalo State University \\ Gorontalo, Indonesia \\ ahmad@ung.ac.id
}

\begin{abstract}
Tinospora crispa is a plant of the Menispermaceae family which is one of the endemic plants in Indonesia, commonly called as Brotowali. T. crispa is traditionally used to treat diabetes, rheumatism, sinusitis and fever. The purpose of this study was to determine the molecular structures of isolated compound of methanol fraction from $T$. crispa stem bark. Extraction using maceration method with $n$-hexane, ethyl acetate and methanol as solvents. The structures of compounds were elucidated with spectroscopic data $\left({ }^{1} \mathrm{H},{ }^{13} \mathrm{C}\right.$, DEPT $135^{\circ}$, HMBC, HMQC, ${ }^{1} \mathrm{H}^{1}{ }^{1} \mathrm{H}$ COSY NMR, IR) and MS as well as compared with previously reported spectral data. The structure of isolated compound was finally identified as 24(R)-

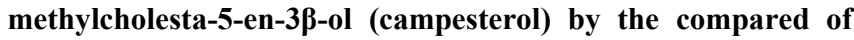
several physical and spectral data with the literature. In previously study, campesterol have antiangiogenic and anticholesterol activities.
\end{abstract}

Keywords-Tinospora crispa, campesterol, Menispermaceae, brotowali

\section{INTRODUCTION}

The Tinospora crispa (Brotowali) of Menispermaceae family are used in the form of decoction to treat cholera and hypertension [1]. T. crispa is traditionally used for the treatment of gout and reported as analgesic, anti-inflammatory, and antihyperuricemic agents. T. crispa of Menispermaceae family is well known as a bitter medicinal plant but it has various efficacy and has been empirically used to treat rheumatism, cholera, diabetes, gout, bruise, hypertension, hypoglycemia, and fever [2][3][4].

Chemical compounds of $T$. crispa were reported as flavonoids, tinocrisposide, steroids, columbine, quaternary alkaloids, saponins, tannins, glycosides, and polyphenols [5][6][7]. Other studies have shown that T. crispa stem extract contains anti-inflammatory [9][7] and analgesic properties [8]. T. crispa has the potential compounds to be developed as a raw material of standardized herbal medicine or phytopharmaca.

This plant is very widely used in Indonesia as an herbal medicine, so it is necessary to know the content of secondary metabolites in the T. crispa plant. In this research, the methanol fraction was subjected to chromatographic separation to afford steroid compound (24(R)methylcholesta-5-en-3 $\beta$-ol). This compound was first isolated from T. Crispa which was obtained from Gorontalo.

\section{METHOD}

The Tinospora crispa was collected at Bubaa village, Boalemo district, Gorontalo, Indonesia in May 2016. It was identified in Herbarium Biology, Faculty of Mathematics and Natural Sciences, Gorontalo State University. The chemicals used in this research are $n$-hexane, ethyl acetate, distilled water, methanol $96 \%$, thin layer chromatography (TLC) silica plate, silica gel G60 (70-320 mesh), TLC, 10\% $\mathrm{H}_{2} \mathrm{SO}_{4}$ in ethanol, and ethanol $70 \%$.

Spectrum measurements were performed using a Infrared spectrometer (Shimadzu FTIR), a ESI-MS spectrometer (UPLC MS/MS TQD type Waters), ${ }^{1} \mathrm{H}$ and ${ }^{13} \mathrm{C}$-NMR spectrometers were measured using a modern NMR spectrometer (JEOL JNMA-500) which works on frequency $500 \mathrm{MHz}$..

Extraction and isolation: Dried T. crispa stem bark (700 g) were soaked in $3 \mathrm{~L}$ methanol $96 \%$ for 3 days. Then the mixture filtered and the filtrate was evaporated under reduce pressure at $45^{\circ} \mathrm{C}$ using a Rotary Evaporator to provide $21 \mathrm{~g}$ of a gummy concentrate of the crude extract. It was then fractionated with $n$-hexane and followed by ethyl acetate. All extracts were filtered using Whatmann filter paper and corked with cotton, then concentrated by using a vacuum rotary evaporator to provide extracts.

Chromatographic separation: The thin-layer chromatographic (TLC) grade silica gel G60 has already been used in column as the packing material. Then the methanol fraction is entered into column chromatography, and eluted using $n$-hexane followed by mixture of $n$-hexaneethyl acetate gradient $10 \%$. A total of 11 fractions (01-11) were collected each in $150 \mathrm{~mL}$ beakers. The fraction 4 and 5 $(0.40 \mathrm{~g})$ was throug to column chromatography over silica gel Kieselgel G60 (mesh 70-230) using a eluent mixture of n-hexane : ethyl acetate (9:1), affording 40 fractions (5.601-5.6-40). Fraction 5.6-09 was found to yield crystal on the wall of the beakers. As a final result a needle-shaped crystal is obtained again, and the crystal can be called to be isolated. to determine pure isolates can be done with TLC and ODS using several solvent systems and showed a single spot ( $>90 \%$ pure).

Test for steroid with Liebermann-Burchard reaction: A crystals isolate was dissolved in chloroform and added a few drops of sulfuric acid and followed by the addition of 23 drops of acetic anhydride. After being added, the isolate 
turns blue violet and finally forms a green color, which indicates steroids.

\section{RESULTS AND DISCUSSION}

Data from the isolated compound gives molecular formulas $\mathrm{C}_{29} \mathrm{H}_{48} \mathrm{O}$, which was supported by the ${ }^{13} \mathrm{C}$-NMR and ${ }^{1} \mathrm{H}-\mathrm{NMR}$ data spectrum.

\section{Characterization of Isolated Compound}

The isolated compound showed characteristic absorption frequencies IR spectrum $(\mathrm{KBr})$ at $3373.6 \mathrm{~cm}^{-1}$ $\left(\mathrm{O}-\mathrm{H}\right.$ stretching); and $1241 \mathrm{~cm}^{-1}$ indicated $\mathrm{C}-\mathrm{O}$ bond vibrations. The $\mathrm{C}=\mathrm{C}$ vibrations was shown at $1638.8 \mathrm{~cm}^{-1}$; other absorption peaks includes $1454.2 \mathrm{~cm}^{-1}$ $\left(\mathrm{CH}_{2}\right)$; vibrations at $1383.7 \mathrm{~cm}^{-1}(\mathrm{O}-\mathrm{H}), 1045.5 \mathrm{~cm}^{-1}$ (cycloalkane), and $883.6 \mathrm{~cm}^{-1}[10]$.
The ${ }^{1} \mathrm{H}-\mathrm{NMR}\left(500 \mathrm{MHz}, \mathrm{CDCl}_{3}, \mathrm{ppm}\right)$ spectra of isolated compound showed $\delta_{\mathrm{H}} 5.34(1 \mathrm{H}, \mathrm{m}, \mathrm{H}-6), 3.52(1 \mathrm{H}, \mathrm{dd}, J=$ 7.3, $7.3 \mathrm{~Hz}, \mathrm{H}-3), 2.28$ (1H, d, $J=7.3 \mathrm{~Hz}, \mathrm{H}-4), 1.01(3 \mathrm{H}, \mathrm{s}$, $\mathrm{H}-19), 0.92(1 \mathrm{H}, \mathrm{d}, J=6.6 \mathrm{~Hz}, \mathrm{H}-21), 0.84(3 \mathrm{H}, \mathrm{d}, J=7.2$ $\mathrm{Hz}, \mathrm{H}-27), 0.81$ (3H, d, $J=7.2 \mathrm{~Hz}, \mathrm{H}-26), 0.80$ (3H, d, $J=$ $7.0 \mathrm{~Hz}, \mathrm{H}-28)$, and 0.68 (3H, s, H-18). ${ }^{13} \mathrm{C}-\mathrm{NMR}(125 \mathrm{MHz}$, $\left.\mathrm{CDCl}_{3}, \mathrm{ppm}\right)$ spectra of isolated compound showed $\delta_{\mathrm{C}} 140.9$ (C-5), 121.9 (C-6), 71.9 (C-3), 56.9 (C-14), 56.1 (C-17), 50.1 (C- 9), 42.4 (C-24), 42.3 (C-4), 42.3 (C-13), 39.8 (C-12), 37.3 (C-1), 36.5 (C-10), 36.1 (C-25), 33.8 (C-22), 31.8 (C-7), 31.8 (C-20), 29.8 (C-8), 28.4 (C-2), 28.4 (C-16), 24.4 (C-28), 21.2 (C-15), 21.2 (C-23), 19.5 (C-18), 21.2 (C-11), 19.5 (C21), 19.0 (C-27), 21.2 (C-26), and 12.0 (C-19). The data spectrum values ${ }^{1} \mathrm{H}$ and ${ }^{13} \mathrm{C}-\mathrm{NMR}$ were assigned on the basis of COSY, HMBC and HMQC correlations and were given $\mathrm{i}$

TABLE I. IN ADDITION, THE DATA SPECTRUM ${ }^{1} \mathrm{H}$ AND ${ }^{13} \mathrm{C}-\mathrm{NMR}$ IS SUPPORTED BY COMPARATIVE LITERATURE

\begin{tabular}{|c|c|c|c|c|c|c|c|}
\hline \multirow{2}{*}{$\begin{array}{l}\text { Position } \\
\text { C }\end{array}$} & \multirow{2}{*}{$\begin{array}{c}{ }^{13} \mathrm{C}-\mathrm{NMR} \delta \mathrm{C} \\
(\mathrm{ppm})\end{array}$} & \multirow{2}{*}{$\begin{array}{l}\text { DEPT } \\
135^{\circ}\end{array}$} & \multirow{2}{*}{$\begin{array}{c}{ }^{1} \mathrm{H}-\mathrm{NMR} \\
\delta_{H}(\text { Int., mult., } J=H z)\end{array}$} & \multirow{2}{*}{$\begin{array}{c}\text { HMBC } \\
{ }^{1} \mathrm{H} \text { to }{ }^{13} \mathrm{C}\end{array}$} & \multirow{2}{*}{$\begin{array}{c}\text { COSY } \\
{ }^{1} \mathbf{H}-{ }^{1} \mathbf{H}\end{array}$} & \multicolumn{2}{|c|}{ Comparative Literature $[11][12]$} \\
\hline & & & & & & ${ }^{1} \mathrm{H}$-NMR & ${ }^{13} \mathrm{C}-\mathrm{NMR}$ \\
\hline 1 & 37.3 & $\mathrm{CH}_{2}$ & $0.97(1 \mathrm{H} ; \mathrm{m}) ; 1.55(1 \mathrm{H} ; m)$ & C-10,3 & H- 3 & & $37.3[11][12]$ \\
\hline 2 & 28.4 & $\mathrm{CH}_{2}$ & $1.52(2 \mathrm{H} ; m)$ & C-4 & - & & $28.2[12]$ \\
\hline 3 & 71.9 & $\mathrm{CH}$ & $3.52(1 \mathrm{H} ; d t, 11.0 ; 3.9)$ & - & $\mathrm{H}-1$ & $3.51(1 \mathrm{H})[12]$ & $71.8[12]$ \\
\hline 4 & 42.3 & $\mathrm{CH}_{2}$ & $1.4(2 \mathrm{H} ; m)$ & - & - & & $42.3[12]$ \\
\hline 5 & 140.9 & $\mathrm{Cq}$ & - & - & - & & $140.8[11]$ \\
\hline 6 & 121.9 & $\mathrm{CH}$ & $5,3(1 \mathrm{H} ; m)$ & $\mathrm{C}-4,8,10$ & - & $5,34(1 \mathrm{H} ; m)[12]$ & $121.7[12]$ \\
\hline 7 & 31.8 & $\mathrm{CH}_{2}$ & $1.33(2 \mathrm{H} ; t, 3.6)$ & - & - & & $31.7[11][12]$ \\
\hline 8 & 29.8 & $\mathrm{CH}$ & $1.73(1 \mathrm{H} ; m)$ & - & - & & \\
\hline 9 & 50.1 & $\mathrm{CH}$ & $1.53(1 \mathrm{H} ; m)$ & - & - & & $50.1[12]$ \\
\hline 10 & 36.5 & $\mathrm{Cq}$ & - & - & - & & $36.5[12]$ \\
\hline 11 & 21.2 & $\mathrm{CH}_{2}$ & $1.13(2 \mathrm{H} ; m)$ & C-9, 12 & $\mathrm{H}-12$ & & \\
\hline 12 & 39.8 & $\mathrm{CH}_{2}$ & $1.21(2 \mathrm{H} ; t, 3.9)$ & C-9, 18 & $\mathrm{H}-11$ & & $40.0[12]$ \\
\hline 13 & 42.3 & $\mathrm{Cq}$ & - & - & - & & $42.28[11]$ \\
\hline 14 & 56.9 & $\mathrm{CH}$ & $1.83(1 \mathrm{H} ; m)$ & - & - & & $56.9[12]$ \\
\hline 15 & 21.2 & $\mathrm{CH}_{2}$ & $1.50(2 \mathrm{H} ; m)$ & - & - & & \\
\hline 16 & 28.4 & $\mathrm{CH}_{2}$ & $1.53(1 \mathrm{H} ; m) ; 1.92(1 \mathrm{H} ; m)$ & - & - & & \\
\hline 17 & 56.1 & $\mathrm{CH}$ & $1.73(1 \mathrm{H} ; m)$ & - & - & & $56.1[11][12]$ \\
\hline 18 & 19.5 & $\mathrm{CH}_{3}$ & $1.10(3 \mathrm{H} ; d, 6.0)$ & $\mathrm{C}-12,21$ & $\mathrm{H}-22$ & & \\
\hline 19 & 12.0 & $\mathrm{CH}$ & $2.07(2 \mathrm{H} ; m)$ & - & - & & \\
\hline 20 & 31.8 & $\mathrm{CH}_{2}$ & $2.17(\mathrm{H} ; m)$ & - & - & & $31.7[11]$ \\
\hline 21 & 19.5 & $\mathrm{CH}$ & $1.30(\mathrm{H} ; m)$ & - & - & & \\
\hline 22 & 33.8 & $\mathrm{CH}$ & $1.90(1 \mathrm{H} ; m)$ & - & $\mathrm{H}-18$ & & $33.9[12]$ \\
\hline 23 & 21.3 & $\mathrm{CH}_{2}$ & $1.2(2 \mathrm{H} ; m)$ & $\mathrm{C}-3,5,24$ & - & & \\
\hline 24 & 42.4 & $\mathrm{CH}_{3}$ & $1.08(3 \mathrm{H} ; t)$ & - & - & & \\
\hline 25 & 36.1 & $\mathrm{CH}$ & $1.77(1 \mathrm{H} ; m)$ & $\mathrm{C}-5,9,10$ & - & & $36.1[12]$ \\
\hline 26 & 21.2 & $\mathrm{CH}_{3}$ & $0.84(3 \mathrm{H} ; d, 6.4)$ & C-8, 9, 14 & - & & \\
\hline 27 & 19.0 & $\mathrm{CH}_{3}$ & $1.17(3 \mathrm{H} ; d, 6.4)$ & $\mathrm{C}-8,13,14,15$ & - & & \\
\hline 28 & 24.4 & $\mathrm{CH}_{3}$ & $0.7(3 \mathrm{H} ; s)$ & - & - & & \\
\hline 29 & 12.4 & $\mathrm{CH}_{3}$ & $0.98(3 \mathrm{H} ; s)$ & $\mathrm{C}-21$ & - & $0.98(3 \mathrm{H} ; s)[11]$ & \\
\hline
\end{tabular}


The ${ }^{13} \mathrm{C}-\mathrm{NMR}$ (ppm) spectrum showed six methyl $\left(\mathrm{CH}_{3}\right)$ groups and one olefenic group at $\delta_{\mathrm{C}} 140.9(\mathrm{C}-5)$ and 121.9 (C-6). The deshielded signal at $\delta_{\mathrm{C}} 71.9 \mathrm{ppm}$ was due to $\mathrm{C}-3$ with a hydroxyl group attached. The proton corresponding to the $\mathrm{H}-3$ of a sterol moiety was appeared as a triplet of doublet of doublets at $\delta_{\mathrm{C}} 3.52 \mathrm{ppm}$. Isolated compound also showed protons at $\delta_{\mathrm{H}} 5.34 \mathrm{ppm}$ suggesting the presence of a proton corresponding to that of a olefinic bond [11][12]. Thus, the structure of isolated compound was assigned as $(24(R)$-methylcholesta-5-en-3 $\beta-\mathrm{ol})$ (campesterol). The physical and spectral data are consistent to the reported literature values of campesterol (Fig. 1).<smiles>CC(C)C(C)CCC(C)C1CCC2C3CC=C4CC(O)CCC4(C)C3CCC12C</smiles>

Fig. 1. Isolated compound (campesterol)

\section{CONCLUSION}

The characterization of the isolated compounds as 24(R)-methylcholesta5-en-3 $\beta$-ol (campesterol) by the comparison of several physical and spectral data with the literature.

\section{ACKNOWLEDGMENT}

The author thank to Mrs. Sofa Fajriah, M.Si as well as Dr. Achmad, M.Si for their help in conducting the NMR measurement.

\section{REFERENCES}

[1] Z. Amom, H. Bahari, S. Isemaail, N. A. Ismail, Z. M. Shah, and M. S. Arsyad, "Nutritional composition, antioxidant ability and flavonoid content of Tinospora crispa stem," Adv. Nat. Appl. Sci., vol. 3, no. 1, pp. 88-95, 2009.

[2] S. Dalimartha, Resep tumbuhan obat untuk asam urat. Niaga Swadaya, 2008

[3] He. Na. ZulkEfli, J. Mohamad, and N. Z. Abidin, “Antioxidant activity of methanol extract of Tinospora crispa and Tabernaemontana corymbosa," Sains Malaysiana, vol. 42, no. 6, pp. 697-706, 2013.

[4] S. Ounjaijean, S. Chachiyo, and V. Somsak, "Hypoglycemia induced by Plasmodium berghei infection is prevented by treatment with Tinospora crispa stem extract," Parasitol. Int., vol. 68 , no. 1 , pp. 57-59, 2019.

[5] A. P. Sudarsono, D. Gunawan, S. Wahyono, I. A. Donatus, M. Dradjad, and S. N. Wibowo, Tumbuhan Obat, Hasil Penelitian, Sifat-Sifat dan Penggunaan. Yogyakarta: Pusat Penelitian Obat Tradisional (PPOT) UGM, 1996.

[6] Handayani, "Efek Antiangiogenik Ekstrak Kloroform Batang Tinospora crispa pada Membran Korio Alantoin Embrio Ayam Terinduksi bFGF," Indones. J. Pharm., vol. 2, no. 1, pp. 124$128,2010$.

[7] A. Z. Adnan et al., "In Vitro Anti-Inflammatory Activity Test of Tinocrisposide and freeze-Dried Aqueous Extract of Tinospora crispa stems on Human Red Blood Cell by Increasing Membrane Stability Experiment," vol. 12, no. 5, 2019.

[8] M. R. Sulaiman, Z. A. Zakaria, and R. Lihan, "Antinociceptive and anti-inflammatory activities of Tinospora crispa in various Animal models," Int J Trop Med, vol. 3, pp. 66-69, 2008.

[9] R. L. B. Hipol, M. Cariaga, and R. M. Hipol, "Anti-inflammatory activities of the aqueous extract of the stem of Tinospora crispa (Family Menispermaceae)," J Nat Stud, vol. 11, pp. 88-95, 2012.

[10] M. F. de Araújo, R. Braz-Filho, M. G. de Carvalho, and I. J. C. Vieira, "Other compounds isolated from Simira glaziovii and the ${ }^{1} \mathrm{H}$ and $13 \mathrm{C}$ NMR chemical shift assignments of new 1-epicastanopsol," Quim. Nova, vol. 35, no. 11, pp. 2202-2204, 2012.

[11] P. S. Jain and S. B. Bari, "Isolation of lupeol, stigmasterol and campesterol from petroleum ether extract of woody stem of Wrightia tinctoria," Asian Journal of Plant Sciences, vol. 9, no. 3. pp. 163-167, 2010.

[12] J. Choi et al., "Identification of campesterol from Chrysanthemum coronarium L. and its antiangiogenic activities," Phyther. Res., vol. 21, no. 10, pp. 954-959, 2007. 